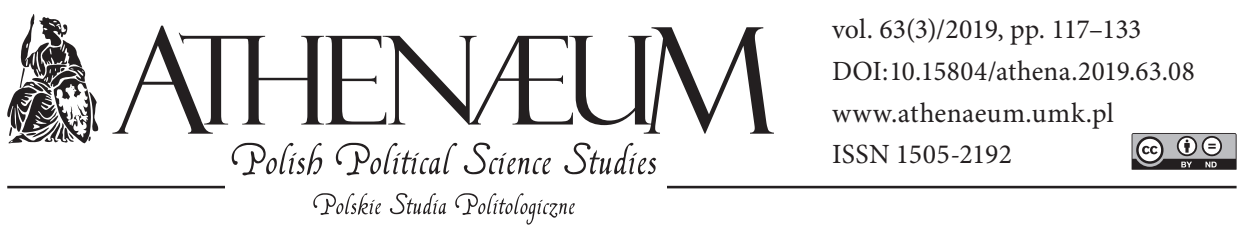

\title{
LOCAL GOVERNMENT POLICY IN THE FIELD OF EDUCATION AND HEALTH IN POLAND AFTER 2015
}

\author{
POLITYKA SAMORZAZDU TERYTORIALNEGO \\ W SFERZE EDUKACII I ZDROWIA W POLSCE PO 2015 ROKU
}

Paweł Grzywna* ๑, Natalia Stępień-Lampa**

\begin{abstract}
The considerations in the article focus on the role of territorial local government in two important spheres of welfare state - in providing access to education, and health care. The authors characterize the situation in Poland after the parliamentary elections won in 2015 by the Law and Justice (PiS). The first part of the study analyses the reforms undertaken in the education system and their consequences for territorial local government, in particular increasing the compulsory education age as well as changing the school system. The second part contains a description of planned and implemented changes in health care.
\end{abstract}

Keywords: education; health; local government; reform
Rozważania prowadzone w artykule koncentrują się wokół roli samorządu terytorialnego w dwóch istotnych sferach działania państwa typu welfare state - w zapewnieniu dostępu do edukacji oraz w ochronie zdrowia. Autorzy charakteryzują sytuację w Polsce po wygranych w 2015 roku przez Prawo i Sprawiedliwość wyborach parlamentarnych. W pierwszej części opracowania analizie poddano reformy podjęte w systemie oświaty i ich konsekwencje dla samorządu terytorialnego, $\mathrm{w}$ tym przede wszystkim podwyższenie wieku obowiązkowej edukacji, a także zmianę ustroju szkolnego. Druga część zawiera natomiast opis planowanych oraz wdrożonych zmian w ochronie zdrowia.

Słowa kluczowe: edukacja; zdrowie; samorząd terytorialny; reforma

* University of Silesia in Katowice, Faculty of Social Sciences.

** University of Silesia in Katowice, Faculty of Social Sciences. 
Ensuring access to health care and education financed from public funds is one of the guarantees of social security. These obligations in Poland - in accordance with the principle of decentralisation of state power - are largely implemented by local government. Therefore, attaining citizens' state of security in the social dimension will depend, inter alia, on the condition of the local government. In this study, the policy of local government in the sphere of health care and education was analysed - in the period after taking over the central power by the Law and Justice Party. The purpose of this study is to analyse the policy of local government in the field of education and health after the assumption of central authority by Law and Justice. This will make it possible to formulate proposals primarily addressed to local authorities in these two dimensions of public policy. This intention was possible to implement thanks to the method of document analysis. It was subjected to content posted by state institutions in official documents (including those of strategic importance), legal acts, as well as on websites. Literature studies have also been made in the study.

\section{THE ROLE OF LOCAL GOVERNMENT IN THE FIELD OF EDUCATION}

Education in a welfare state is one of the areas of activity of public authority both in the central and local dimensions. In Poland, a significant part of the tasks in this field lies with the local government, in particular, the municipality and county. What is more, the characteristic feature of the Polish education system is that it is subject to numerous transformations. As a consequence, the local government is obliged to implement the reforms planned by the subsequent ministries of education.

In 2015, as a result of winning the parliamentary elections, the Law and Justice Party came to power in Poland. On 16 November 2015, Beata Szydło’s cabinet was sworn in, and on 11 December 2017, Mateusz Morawiecki became the Prime Minister. Both in the first as well as in the second PiS government, Anna Zalewska was the Minister of Education. In accordance with the announcements made during the election campaign in 2015, the Ministry of Education almost immediately started to work on a thorough change of the education system, whose face became Minister A. Zalewska.

The change in the education system initiated in 2016-2017 by the ministry led by A. Zalewska can be described as a counter-reform. As a result, a structure of education similar to that before the reform undertaken by the Ministry of 
Education, headed by Mirosław Handke, would be established. As a result of changes initiated in 1998-1999, among others, education in primary school was shortened to 6 years, 3-year junior high schools, 3-year general secondary schools and specialised secondary schools, 4-year technical schools, 2- and 3-year basic vocational schools, as well as 2-year secondary schools for general education and 3 -year technical complementary schools, and post-secondary schools were created. This school structure was then subject to further transformations, as a result of which, inter alia, specialised secondary schools as well as complementary schools were closed (Dyrda, Koczoń-Zurek, \& Przybylska, 2008, pp. 48-55).

The first reform in the education system taken up by PiS was the restoration of the compulsory schooling for 7-year-old children and obligatory pre-school education for 6-year-olds from 2016/2017. On 29 December 2015, the Act amending the Act on the education system and certain other Acts was passed. This was one of the first legislative acts adopted by the Sejm of the $8^{\text {th }}$ term. The law also confirmed the right of children aged 3 to 5 to pre-school education and the municipalities were obliged to provide conditions for the implementation of this right for 4- and 5-year-olds (from the 2017/2018 school year this obligation applies to 3-year-old children). At the same time, children born in 2008 who started school as 6-year-olds were guaranteed the possibility of repeating the second grade, and children born in 2009, who also went to school at the age of 6 the first grade. The decision in this regard belonged to parents or legal guardians of children and had to be taken by 31 March. In addition, the Act ensures that in the school year 2016/2017, a branch of the first grade will be opened if 7 students gather in rural areas or in cities up to 5,000 inhabitants, and 11 in larger cities. The last of the indicated provisions was based on a threat that in many schools it will not be possible to create a single unit, and therefore children will have to attend establishments located far away from their place of residence.

Increasing the age of compulsory education forced local governments to take action aimed at adapting to the new regulations. The centrally implemented change caused many negative consequences at the local level. Parents' decision to leave 6-year-olds in the zero grade (which are now usually organized in preschool establishments) was associated with the risk of not being able to open branches in kindergartens for 3-year-olds, which could result from the lack of sufficient places. In addition, there were difficulties connected with the organisation of primary school education. As indicated by the estimates of the Ministry of Education, $80 \%$ of 6-year-olds were left in kindergartens and, therefore, fewer first-grade units were launched than in previous years (Ministerstwo Edukacji 
Narodowej, 2016a). This, in turn, could cause problems with ensuring working hours for teachers of early school education and forcing local governments to reduce their posts. Increasing the compulsory education age had also adverse financial consequences for municipalities, namely the depletion of funds from the central budget for the implementation of educational tasks by the local government. In order to co-finance the organisation by the municipalities, preschool education received a targeted subsidy, while for the implementation of other tasks in the field of education, the leading authorities received and are receiving the educational part of the general subsidy. After the measures taken by the Ministry of Education aimed at increasing the subsidy, it amounted to PLN 1,370, in turn, the amount of the so-called educational subsidy is about PLN 5,300 (Ministerstwo Edukacji Narodowej, 2016b; Serwis Samorządowy PAP, 2016). The indicated sums were transferred for the whole calendar year, the subsidy was increased from September, so the increased amount received by the local government was proportionally calculated for a period of four months (Regulation, 2015). In order to compensate for this loss, a decision was made according to which in the next budget year - from 1 January 2017 - the educational part of the general subsidy is calculated for 6-year-old children regardless of whether they receive education in the first grade or are subject to mandatory pre-school education (Regulation, 2016).

Less than a year after raising the compulsory school education age - on 14 December 2016, a new law regulating issues related to education was passed - the Education Law Act (Journal of Laws of 2017, item 59). Undertaking the process of reforming education was argued by the Ministry of Education of not meeting the assumptions made before the junior high school (in the view of ministry), which was primarily the equalisation of educational opportunities and the improvement of the results and quality of teaching. In addition, it was pointed that these schools were to be programmatically connected with upper secondary schools, while they often functioned in an organisational form with primary schools. The Ministry of Education also pointed to the fact that due to the demographic decline in the future there will be problems with financing junior high schools, which will be experienced by local governments (Ministerstwo Edukacji Narodowej, 2018).

After the reform, the structure of the education system will be determined by: 8 -year primary schools, 4-year general secondary schools, 5-year technical schools, 3-year first-level trade schools, 2-year second-level trade schools. The assumptions of the change are being implemented gradually - according to its 
schedule, as of 1 September 2017, students of the 6-year primary school became students of the 8-year school, and sixth grade graduates began education in the seventh grade. On the $1^{\text {st }}$ of September 2018, the eighth grade was created. In addition, gradual phasing out of junior high schools was initiated, and basic vocational schools will be transformed into 3-year first-level trade schools (2-year second-level trade schools will be established on 1 September 2020). Eventually, the junior high school will cease to function from 1 September 2019, and the entire reform will end in 2023 (then the last year of junior high school graduates will complete 4-year technical schools).

The assumptions of the reform caused a lot of controversy. The intentions of the Ministry of Education were criticised by some of the teachers gathered around the Polish Teachers' Union (the largest union of representatives of this professional group). On 31 March 2017, the PTU organised a strike of education professionals, and the strikers' demands concerned the maintenance of jobs and pay rises (similar demands were also made in 2019). Teachers were primarily afraid that as a result of the reform a significant number of them would lose their jobs (although Minister A. Zalewska consistently denied this). Contrary to the announcements of the Ministry of Education, some local government officials also pointed that the change would inevitably involve teachers' dismissals.

As a result of the implementation of the reforms, until 31 March 2017 local government units were obliged to adopt resolutions on the adjustment of the school network to the new education system. However, these projects had to get a positive opinion of the competent school superintendent in terms of territorial coverage, and the latter had 21 days to issue it. Thus, in the first quarter of 2017, at the local government level, decisions were made about which schools will operate, and what will happen to premises after former junior high schools. For local government units, the initial years of implementing the reforms of education are particularly difficult. The critical moment will be the school year 2019/2020, because in the first grade of high school, technical school and trade school, graduates of 6-year primary and 3-year junior high schools and graduates of 8-year-old primary schools will learn, which may cause difficulties for the local government with ensuring appropriate number of places in these establishments.

An important change from the point of local government responsibilities, indirectly related to the education system, was introduced by the ruling party in 2018. The Good Start programme was launched, under which, in relation to the start of the school year, one can receive a benefit on the same name (Regulation, 2018). The entitlement to the benefit is provided in connection with the 
beginning of the school year for parents, actual guardians, legal guardians, foster families, people running foster family homes, directors of childcare centres, directors of regional care and therapy centres - once a year for a child; as well as for adult and non-dependent learners - once a year. They can be received by a child or a person studying at the age of 20 or by a child or a learner of the age of 24 - in the case of children or learners with a certificate of disability. A Good Start benefit is also granted if a child or a learner is 20 years of age before the start of the school year in the calendar year in which the child or learner turns 20 , or reaches the age of 24 by a child or learner before the start of the school year in the calendar year in which the child or learner turns 24 - in the case of children or learners with a disability certificate. The amount of Good Start benefit is PLN 300 and, what is important, regardless of the income earned. In case the child - in accordance with the court decision - is under alternate custody of both divorced parents who are separated or separated in comparable and recurring periods, the amount of Good Start is determined for each parent in the amount of half of benefit entitlement.

The main burden of responsibility for the organisation of the payment of the benefit was assigned to the municipal government and - to a lesser extent - the county. Pursuant to the regulation that governs the Good Start benefit, the proceedings concerning the benefit are carried out in the municipal organisational unit in which matters concerning the payment of parental benefit (i.e., the so-called 500+) or in the county's organisational unit in the case of children placed in foster care or learners who are persons in independent living (the latter category includes, inter alia, persons leaving - after reaching the age of maturity - foster families, family orphanages, care and educational centres). In order to familiarise the local governments with detailed programme guidelines, the website of the Ministry of Family, Labour and Social Policy launched a special information service, where a guide for municipalities and counties has been included. Applications for payment of money under the Good Start programme can be submitted to the competent authority from 1 August of a given year to 30 November of a given year. However, in case of applications submitted electronically, this deadline is longer and starts on 1 July and ends on 30 November (Regulation, 2018).

As estimated by MFLSP, support under the Good Start programme will cover 4.6 million students in 2018. Importantly, before the end of the summer holidays, 2.33 million applications were filed (Ministerstwo Rodziny, Pracy i Polityki Społecznej, 2019). Implementation of the benefit forced the necessity 
of intensive work in organisational units of municipalities and counties, which were burdened with running it. In many local governments there were problems with the staff, which also overlapped with the holiday period. In response to these problems, the Ministry provided additional funds to the local government units to cover the costs of servicing the task, to enable additional employment. However, despite these activities, many municipal and county offices experienced problems, and civil servant officials worked on weekends and over-working hours (Topolewska, 2018).

Poland's education policy - in accordance with the constitutional principle of decentralisation - is largely implemented by local government. For this reason, local government units are responsible for any changes introduced at the central level in the education system. After winning the 2015 parliamentary elections, the Law and Justice Party began to implement fundamental reforms in education. The biggest of them - which will end in 2023 - is the change of the education system. All measures carried out by PiS were implemented and are being implemented by local government. It often causes resistance and reluctance of local government officials, as well as the necessity of undertaking additional and new tasks by officials.

Interestingly, a completely different model of education management occurs in Finland (Sahlberg, 2011). In this Scandinavian country, the last major reform of education took place in 1970 and was preceded by several years of research and consultations. This approach to education policy brings about very good results of young Finns in the PISA (Programme for International Student Assessment), and solutions adopted in Finland are a source of inspiration for many experts in education (Zahorska, 2017). Meanwhile, in the Polish context, as long as education is a bargaining chip in the hands of politicians and there is no consensus across party lines, education reforms will continue to be carried out extremely frequently. Their direct implementation will in turn be the responsibility of the local government and will force continuous shaping of new local and regional education policies by local government.

\section{LOCAL GOVERNMENT ROLE IN THE FIELD OF HEALTH CARE}

As has already been mentioned, as a result of the parliamentary elections won in 2015, the power in Poland was de facto taken over by the Law and Justice Party. In the appointed cabinet of Beata Szydło, the function of Minister of Health was 
held by Konstanty Radziwiłł - until 9 January 2018, when the Prime Minister Mateusz Morawiecki reconstructed the government and entrusted this function to Łukasz Szumowski.

During the election campaign, the Law and Justice Party in its election programme Health. Work. Family (Zdrowie. Praca. Rodzina, 2014) had already proposed deep changes in the area of social infrastructure, also in the field of health policy. The proposals for the reform of the healthcare system covered mainly the liquidation of the National Health Fund (NHF) and a shift towards planning expenditure from the state budget, to which the health insurance premium was also to be brought back (transition from the insurance model to the procurement-budget model). With the expenditure on the system raised to $6 \%$ of GDP, the Ministry of Health was in fact the only entity responsible for preparing a plan for financing benefits, including a plan for allocating funds to individual regions, and regional governors were to be accountable for benefit funding at the regional level.

The PiS Party also emphasized the importance of primary health care (PHC) in the healthcare system, which was to guarantee a provision of funds from the state budget for investments and modernisation of healthcare establishments. A targeted Fund for Construction, Modernisation and Maintenance of Public Healthcare Establishments was to be created.

The basic instrument for organizing medical activities was meant be a network of public hospitals arranged according to the needs of the population.

The rules of reimbursement for medication by the state budget were also to be changed - the price of the reimbursed medication in a pharmacy, regardless of its market price, should not exceed PLN 8.00-9.00 (around €2). Setting the upper annual limit of expenses incurred by a patient with low incomes will constitute the second pillar of changes to the provisions on reimbursement of medication, and the limit will be set in the Budget Act.

PiS proposed to improve patients' access to medical services and to shorten queues to specialist clinics by increasing the number of people studying (increasing admissions to medical schools and studies) and employing more specialists. Hospital services were to be financed according to the pay for service rules, for health benefits actually performed, without any limits.

The party's programme also included a provision on the appointment of a nursing insurance covering the costs of care over dependent persons, the establishment of a school medicine system covering the monitoring of children's 
health, prevention, health promotion and early therapy, including reinstatement of dental surgeries and nursing care in schools.

It should be emphasised, however, that often the content of official programmes and declarations of political parties remains only in the sphere of theoretically set objectives, without further practical consequences and implementations. These documents constitute a kind of information about general directions of political change, being an element of the process of making political choices and creating public policies, the final shape of the actually pursued and implemented health policy is influenced by various factors, including socio-political and economic situation, emerging problems or ad hoc political compromises.

Following the announcements made in 2015, the Ministry of Health began working on changing the model of the healthcare system. Due to the fact that a significant part of the tasks in the field of health protection rests with the local government: municipality, county and region, it caused that mainly the local government was forced to implement the reform measures.

At the end of July 2016, Minister Konstanty Radziwiłł presented the assumptions of the reform of the healthcare system and outlined the schedule of their implementation. The main part of the healthcare reform was to start as early as January 2018 - health care was to be provided by the National Health Service which, funded from the state budget, was to be available to all residents. The fundamental premise of the reform was to be a gradual increase in public expenditure on health, while the proposed changes regarded six main areas (Table 1):

1. system of management and financing of health care,

2. organisation of hospital treatment,

3. increasing spending on health protection,

4. primary health care,

5. public health,

6. remuneration in health care (Monitor Zmian w Systemie Ochrony Zdrowia, 2017).

The priorities were subordinated to specific objectives, which, on the one hand, indicated elements for improvement and, on the other, the reform mechanism. The assumptions also seem to fill in the health policy dimensions - the main and fundamental issues related to the implementation of the goals of a viable and effective healthcare system. 
Table 1. Priorities and Strategic Goals of Changes in the Health Care System in Poland in 2016-2018. The Concept of the National Health Service

\begin{tabular}{|l|l|}
\hline Priority I & Creation of an efficient management system of universally available health care \\
\hline Goal 1 & NHF liquidation and universal access to benefits \\
\hline Goal 2 & Reform of heath care management at the regional level \\
\hline Goal 3 & Transfer of health care funds to the budget \\
\hline Priority II & Hospital network \\
\hline Goal 1 & New contract system for hospitals \\
\hline Goal 2 & Combining hospital operations with outpatient care \\
\hline Goal 3 & Creating three stages of hospital activities \\
\hline Priority III & Increasing spending on health care \\
\hline Goal & Map of increasing spending on health care to 6\% of GDP in 2025 \\
\hline Priority IV & New Primary Health Care \\
\hline Goal 1 & Creating a primary health care team \\
\hline Goal 2 & Coordination of care through PHC \\
\hline Goal 3 & Funding for the new primary health care and budget entrusted \\
\hline Priority V & Public Health Authority \\
\hline Goal 1 & Integration of the public health system \\
\hline Goal 2 & Increasing the effectiveness of pro-health activities and health promotion \\
\hline Priority VI & Salary adjustments in health care \\
\hline Goal & Minimum wages for health care \\
\hline
\end{tabular}

Source: own elaboration based on Ministerstwo Zdrowia, 2016.

There were to be implemented system changes announced beforehand, including the replacement of principle of universal health insurance by the principle of universal provision of benefits to all residents in need, which is a manifestation of the implementation of Article 68 of the Constitution of the Republic of Poland. The adoption of such a rule meant that the merit in the continuation of the eligibility verification system for benefits (eWUŚ) was no longer justified.

Funds for the functioning of the healthcare system were to be secured by establishing a new form of the public finance sector of the National Special Purpose Fund, under the name "Health", which, being part of the state budget, would also be provisioned with part of personal income tax receipts in the amount corresponding to today's health insurance premium. The fund was also 
to be supplied with a gradually increasing subsidy from the state budget, and its resources were to be at the discretion of the Minister of Health.

There was also announced a systematic increase in financial contributions to health care - up to the level of $6 \%$ of GDP in 2025. The assumptions of the reform included a map of gradual increase of funds for health care, however postponing the changes in contributions by 10 years allows for the speculation that they will not be implemented. This fact is reinforced by the situation in which, already in 2015, the average spending on health in the European Union was $9.9 \%$ of GDP. The phased postponement of the decision "till later" may therefore cause that Poland will still be last in line of the OECD ranking in 2025.

However, the gradual increase in financing of health care was somewhat accelerated, because under the pressure of several months of protests by resident doctors, Minister Łukasz Szumowski granted his approval for one of the financial demands, which in the legal sphere resulted in the fact that on 5 July 2018, the Sejm passed an amendment to the Act on the Act on healthcare services financed from public funds, according to which public health expenditure is to reach $6 \%$ of GDP already in 2024, and in 2018-2023 it cannot be lower than:

- $4.78 \%$ of GDP in 2018 ,

- $4.86 \%$ of GDP in 2019 ,

- $5.03 \%$ of GDP in 2020 ,

- $5.30 \%$ of GDP in 2021 ,

- $5.55 \%$ of GDP in 2022,

- $5.80 \%$ of GDP in 2023 (Ustawa, 2018).

The new method of financing also intended to include hospitals, which instead of the previous financing of individual hospitalisations and medical procedures, were to receive an annual lump sum for the treatment of patients in specific areas. This solution was considered as optimal one from the point of the sickness risk selection phenomenon. The existing system of valuation of medical procedures applied by the National Health Fund generated a situation in which some procedures were valued higher, others lower, and the result was the division of patients into two categories, more desirable by the institution and those whose treatment is economically unprofitable for a given entity.

Hospitals were to be divided into three stages of activity, creating the socalled network of establishments with three levels of reference (local, regional, provincial) and three specialist levels: specialist-pediatrics, specialist-oncology, and institutes. The network was created on the basis of existing entities and their significance for health safety. The first-degree hospital corresponds to the several 
ward hospital (county), the second level of reference, where the hospital consists of 8 to 10 wards, and the third stage consists of clinical hospitals and former specialist regional hospitals. Hospital treatment reform also assumes a coordinated and effective treatment of patients after a stay in a hospital by guaranteeing continuation of treatment and rehabilitation in a hospital outpatient clinic. In the presented concept of creating three stages of hospital operations, one specialist level - geriatrics - is a noticeable absence, the more so because this absence is strengthened by the context of the rapid aging process of Polish society.

After liquidation of the National Health Fund, a significant part of its competences was to be transferred to the Minister of Health. Regional tasks related to the financing of health services were to be carried out by the appointed Regional Health Authority (RHA), vertically subordinated to the Minister of Health, and horizontally - the regional governor, therefore contrary to what was said in the pre-election declarations of PiS, the regional governors will not take over the competences of NHF branches, and regional health authorities reporting to the ministry. They retained some of the competences of the former NHF (e.g., selecting service providers, overseeing the performance of tasks by medical facilities, controlling the issuing of prescriptions and sick leaves). The division of funds between regions was to be made by the Minister of Health based, inter alia, on information on the number and age structure of the population, morbidity and data from the health needs maps. Therefore, the Regional Health Authorities were to coordinate the implementation of a specific central system of the planned health service.

As a result of implementing the reform assumptions, the Minister, taking over part of the fund's tasks, would also take over all responsibility for the functioning of the healthcare system in Poland, and thus any attempts to avoid responsibility will be made more difficult.

One of the main elements of the reform was the establishment of the Public Health Authority, which had to integrate the whole currently dispersed public health management system in Poland. It was to be made up of institutions such as the State Sanitary Inspection, the State Agency for the Prevention of Alcohol Related Problems and the National Bureau for Drug Prevention. The Public Health Authority would also be responsible for the implementation of the National Health Program for 2016-2020. The danger connected with the fact that the Authority was to be directly subordinated to the Minister of Health was the temptation to centrally manage financial resources, which may also result in the loss of local government units' influence on health services. 
Changes were also to take place in the field of primary health care. There were to be established PHC teams, within which the doctor, nurse, midwife, school nurse, and dietician would cooperate with each other. The introduction of the latter should be considered particularly important in the context of counteracting obesity. However, in order for PHCs to realistically coordinate prevention, health education and treatment of the patient, a physiotherapist or psychologist should be included in the indicated team in order to ensure comprehensive action in the field of patients' health at the PHC level.

$\mathrm{PHC}$ teams were also to coordinate and navigate the patient in the healthcare system, e.g., by collecting information on the history of treatment of patients who received help in hospitals or in specialised care rooms. In the assumptions, the general practitioner would receive appropriations for the salaries of specialist doctors, but thereby the GP would become responsible for providing genuine access to them. The existing referral from the general practitioner to the specialist doctor does not guarantee the patient that in the sense of time availability and treatment effectiveness their health need will be satisfied. As a result, many patients decide on treatment by specialists for private money, which results in inequality in access to benefits.

The announced changes have been prepared for gradual implementation, so that at least in the assumptions, to guarantee patients health safety and stable functioning of health system entities.

The first phase of the reform, including Priority II and Priority IV (financing of hospitals and primary health care), was to be implemented from July 2017 - the hospital network started to operate only from 1 October 2017. At the declarative level, the network was presented as a panacea for the problems of the healthcare system, and its main advantage was to become a change in the method of financing - from paying for the procedures performed to a fixed lump sum. The proposed change was supposed to make doctors focus on treating the patient, not bureaucratic procedures. An important assumption was also limiting the phenomenon of patient selection. In many cases, however, the change carries the features of the pretence. It can still be observed that hospitals make a kind of calculation: it is more beneficial to hospitalise a patient who is "slightly ill" than a long-term patient or a seriously ill one, for whom in a lump sum they will not receive additional funds. Thus, the previous system problem has reappeared.

The introduction of a lump sum system did not also solve another important problem of the hospital treatment system - extending patients' hospitalisation for no apparent medical reason. The previous practice meant that longer hos- 
pitalisation was more advantageously valued, so it was more profitable for the institutions to keep the patient in the hospital for a few days longer. After the introduction of the reform, the above phenomenon continues to exist, although it is caused by slightly different factors - it results from the necessity to prove the expenditure of the institution. Hospitals receiving a lump sum still have to account for its implementation under the unchanged rules, which translates into a "safe" occupancy with a "slightly ill" patient, who does not require high financial expenses at the same time.

From 1 January 2018, the next phase of the reform was to take place - the NHF was to be liquidated, and the health service was to be financed from the state budget. However, by the decision of leader of the ruling party Jarosław Kaczyński, the NHF liquidation was postponed, without indicating the date (Watoła, 2017). The reform has therefore been suspended.

All the changes proposed by the PiS government, and regarding the division of competences, their definition, indicated, at least in the declarative layer, the fact of implementing the program assumptions changing the model of the healthcare system from insurance to budget system. Most of the changes, however, have been presented at such a level of generality that they are closer to the documents characteristic of the election campaign than to the strategy of changing the model of health protection. The most important, and so far the only completed, appear to be changes in the area of the hospital network or a separate mechanism for financing fixed and direct costs of hospitals. The solutions adopted call to mind, to some extent, solutions typical of the British system - National Health Service.

However, taking into account the more pragmatic approach in the analysis, it seems that incurring such large reorganisation costs, with a change that bears many features of facades (and a superficial change) is at least a wasteful activity that will not improve the quality of services and shorten the queues of patients.

Therefore, the Polish health care system is still undergoing constant transformation, and the characteristic feature of these changes is the prevailing temporariness, the play of political interests, subjection to pressure groups or the so-called inheritance of recurring goals. An important problem of Polish health policy is also the lack of continuity of reforms. The above phenomena make it difficult to show structural reform and financing health protection in terms of the gradual process, which would undoubtedly contribute to the more effective achievement of the intended goals, especially the development of a rational model of health policy ensuring a uniform standard of health security for patients. 


\section{CONCLUSIONS}

Poland's educational and health policies are largely implemented by local government units, therefore the responsibility for implementing reforms in the education and healthcare system programmed at the central level is borne by local governments. After winning the parliamentary elections in 2015, the Law and Justice Party began to implement fundamental reforms in education and health care, and if the former ends in 2023, the latter has been ceased, without indicating any further direction of change. The actions carried out so far in this respect cannot be described as a reform, but only as a change in the way services are provided, and only by hospitals. All measures carried out by PiS were therefore entrusted to the implementation of local government units, which results in increased burdens for local governments and officials themselves who have to implement further tasks assigned at the central level.

The reform of the education system implemented by the government of Law and Justice is associated with numerous obligations for local authorities. How self-government officials deal with its implementation will largely determine the future assessment of educational change in terms of success or failure. The crucial year in the reform calendar is the 2019/2020 school year, in which two youths will start secondary school education. It is particularly difficult for teachers, principals and, finally, local education authorities.

In the sphere of education and health, territorial self-government in Poland is only the executor of the decision of the central authority (Sześciło, 2016). For this reason, it has no real impact on the shape or frequency of education or health reforms. From the point of view of local government officials, this may be a drawback. Therefore, it is important for local authorities to recognize well the conditions of the local education and health system, opportunities and threats, as well as its strengths and weaknesses. This will certainly facilitate adaptation to potential changes in the sphere of education and health.

Structural educational reforms are a special challenge for local authorities. They are associated with decisions to close or open school facilities, and thus involve staff changes and directly affect students and their parents. This type of change is the reform implemented by the PiS government and therefore it requires local government to make a special effort to implement it.

The difficult financial situation of these self-governments, especially of small rural communes and poviats, has become an important challenge for the health policy implemented at the level of local government. An additional source of 
problems for local governments, especially poviats, is the situation of hospitals, which is evident in their increasing debt. As a result, for example, small amounts are allocated to health policy programs. Under these conditions, it is increasingly difficult for local governments to finance various forms of prevention or health promotion. Only some of them develop and implement local health policies or implement health policy programs.

Financial obligations and political responsibility of local governments also have no instruments for influencing local and regional health policy, moreover, local governments have no impact on the scale of income of their medical entities.

An equally significant threat to the implementation of health care tasks by local governments is a kind of systemic conflict originating at the border of social systems, e.g., long-term medical care and social assistance activities; education and spa treatment for children; social welfare benefits and care and treatment institutions; environmental forms of social assistance and psychiatric treatment.

An important recommendation should be the implementation of the obligation to create local government health policies, followed by their implementation and monitoring, especially in the field of comprehensive preventive programs. Local governments should also develop and implement strategies to reduce the negative effects of demographic change, which constitute the basic challenge facing the healthcare system in Poland.

\section{REFERENCES:}

Dyrda, B., Koczoń-Zurek, S., \& Przybylska, I. (2008). Podstawy prawne i organizacyjne oświaty. Skrypt dla studentów pedagogiki. Katowice: Wydawnictwo Uniwersytetu Śląskiego.

Ministerstwo Edukacji Narodowej (2016a). Co nowego w roku szkolnym 2016/2017. Retrieved from: https://men.gov.pl/ministerstwo/informacje/co-nowego-w-rokuszkolnym-20162017-najwazniejsze-informacje.html/.

Ministerstwo Edukacji Narodowej (2016b). Retrieved from: http://men.gov.pl/wp-content/uploads/2016/01/list-minister-edukacji-narodowej-do-wojtow-burmistrzowi-prezydentow-miast.docx.

Ministerstwo Edukacji Narodowej (2018). Uzasadnienie projektu ustawy Przepisy wprowadzajace ustawe - Prawo oświatowe. Retrieved from: https://men.gov.pl/ wp-content/uploads/2016/10/uzasadnienie-przepisy-wprowadzajace.pdf.

Ministerstwo Rodziny, Pracy i Polityki Społecznej (2019). Retrieved from: https://www. gov.pl/web/rodzina/dobry-start/.

Ministerstwo Zdrowia (2016). Narodowa Stużba Zdrowia. Strategia zmian w systemie ochrony zdrowia w Polsce na lata 2016-2018. Retrieved from: http://www.archiwum. 
mz.gov.pl/aktualnosci/narodowa-sluzba-zdrowia-minister-konstanty-radziwillprzedstawil-zalozenia-reformy/.

Regulation (2015). Rozporządzenie Ministra Edukacji Narodowej z dnia 22 grudnia 2015 roku w sprawie sposobu podziału części oświatowej subwencji ogólnej dla jednostek samorządu terytorialnego w roku 2016 (Dz.U. poz. 2294).

Regulation (2016). Rozporządzenie Ministra Edukacji Narodowej z dnia 22 grudnia 2016 roku w sprawie sposobu podziału części oświatowej subwencji ogólnej dla jednostek samorządu terytorialnego w roku 2017 (Dz.U. poz. 2298).

Regulation (2018). Rozporządzenie Rady Ministrów z dnia 20 maja 2018 roku w sprawie szczegółowych warunków realizacji rządowego programu „Dobry start” (Dz.U. poz. 1061).

Sahlberg, P. (2011). Finnish Lessons: What Can the World Learn from Educational Change in Finland. New York: Teachers College Press.

Serwis Samorządowy PAP (2016). Retrieved from: http://samorzad.pap.pl/depesze/ wiadomosci_centralne/163043/5-278-1-zlotych--Jest-ostateczna-kwota-czescioswiatowej-na-ucznia-w-tym-roku/.

Sześciło, D. (2016). O powikłanej decentralizacji: instytucjonalny krajobraz systemu usług publicznych w Polsce. Zarzadzanie Publiczne, 4(38), 32-34. DOI: 10.15678/ ZP.2016.38.4.03.

Topolewska, M. (2018). 500+ i 300+: Pracowite wakacje urzędników ze świadczeniami. Retrieved from: https://praca.gazetaprawna.pl/artykuly/1125532,zbieg-terminowwyplaty-swiadczen-500-i-300.html/.

Ustawa z 29 grudnia 2015 roku o zmianie ustawy o systemie oświaty oraz niektórych innych ustaw (Dz.U. z 2016 r., poz. 36).

Ustawa z 14 grudnia 2016 roku Prawo oświatowe (Dz.U. z 2017 r., poz. 59).

Ustawa $z$ dnia 5 lipca 2018 roku o zmianie ustawy o świadczeniach opieki zdrowotnej finansowanych ze środków publicznych oraz niektórych innych ustaw (Dz.U. z 2018, poz. 1532).

Watoła, J. (2017). Oceniamy rząd PiS. Konstanty Radziwiłt, minister zdrowia. Ocena: 2.. Retrieved from: http://wyborcza.pl/7,161576,22650191,oceniamy-rzad-piskonstanty-radziwill-minister-zdrowia-ocena.html?disableRedirects=true.

Zahorska, M. (2017). O tym, jak Finowie reformowali swoje szkolnictwo... i dlaczego im się to udało. Retrieved from: http://krytykapolityczna.pl/swiat/o-tym-jak--finowiereformowali-swoje-szkolnictwo-i-dlaczego-im-sie-to-udalo/.

Zdrowie. Praca. Rodzina (2014). Program Prawa i Sprawiedliwości. Retrieved from: http://pis.org.pl/dokumenty. 